\title{
FURTHER NOTE ON KNOT RECORDS FOR MANITOBA
}

by Martin McNicholl, Zoology Dept., University of Manitoba, Winnipeg

Mr. Gordon J. Smith of Winnipeg. as kindly drawn my attention to two Ianitoba Knot records not included my recent report on this species Blue Jay, 27:28-35). One is of a iale specimen taken at Lake St. lartin on June 13, 1935, and reported The birds of the Lake St. Martin egion, Manitoba by T. M. Shortt and Waller (Contr. Roy. Ont. Mus. ool., No. 10, 51 pp., 1937). These uthors state: "This species can only e recorded as a rare spring and early ummer migrant." The other is an bservation by Mr. Smith and Harold - Hosford of a close group of seven nots observed at West Shoal Lake n May 28, 1961.

In addition, I overlooked a record f eight Knots "noted by Taverner's 937 party" on June 2, 1937 at Reader
Lake, near The Pas (W. E. Godfrey, 1953. Notes on birds of the area of intergradation between eastern prairie and forest in Canada. Bull. No. 128, Ann. Rept. Nat. Mus. 1951-52, 52 pp.). There is also a record of four seen on June 9, 1946 at Crean Lake within the boreal forest of Saskatchewan (J. D. Soper, 1952. The birds of Prince Albert National Park, Saskatchewan. Can. Dept. Res. and Devel. Nat. Parks Branch, Can. Wildl. Ser. Series 2, No. 4, 83 pp.).

I would like to point out a typographical error in my paper (Blue Jay, 27:28-35). The personal communication with D. R. M. Hatch (Table 1) should read 1968, not 1966. The date, June 2, 1968, for his observation at Oak Lake is correct.

\section{A KNOT RECORD FOR THE ALBERTA-SASKATCHEWAN BORDER \\ by Hans Blokpoel, Canadian Wildlife Service, Saskatoon}

On June 16, 1968, my wife and I bserved a Knot resting on the west hore of Cold Lake, which is located ithin the Boreal Forest on the lberta-Saskatchewan border. The ird was observed at English Bay latitude $54^{\circ} 34^{\prime}$ ), a flat, sandy shore. Ve observed the bird from our car or about 15 minutes with telescope nd binoculars, using Peterson's A eld guide to western birds, 1961, and The birds of Alberta by Salt and Vilk, 1966. This observation helps to ll the "considerable gap in locations of Knots] on the prairies" described y Martin K. McNicholl (Blue Jay, $7: 28-35)$.

When discussing this gap in locaons McNicholl remarks that "These actors indicate that there may be wo different pathways involved, one assing through western or central lberta, the other east of Manitoba, nd occasionally through eastern Sasatchewan and Manitoba." I do not think that this hypothesis can be supported. McNicholl takes his data for Alberta mainly from Salt and Wilk who map the Knot's migraton over the eastern part of this province. In Saskatchewan Knots have been observed in the area around Saskatoon for several successive years. Since the number of reporting bird watchers is not large in the area between Saskatoon and the Saskatchewan-Alberta border, it may not be wise to attach much significance to a vacuum for that area.

I agree with McNicholl that more information is needed to determine in more detail the course of the Knot's migration. The fact that all but one of the recent records for southern Saskatchewan involve spring observations might be due (at least partially) to the fact that spring migrants are more conspicuously coloured and usually migrate in larger flocks than fall migrants. 